\title{
The Publicness of Publicly Funded Research
}

Department of Economics Working Paper Series

\section{Albert N. Link*}

University of North Carolina at Greensboro

\section{Caroline S. Wagner}

Ohio State University

July 2021

Working Paper 21-05

economics.uncg.edu 


\title{
The Publicness of Publicly Funded Research
}

\author{
Albert N. Link * \\ Department of Economics \\ University of North Carolina at Greensboro \\ anlink@uncg.edu \\ and \\ Caroline S. Wagner \\ John Glenn College of Public Affairs \\ Battelle Center for Science \& Engineering Policy \\ The Ohio State University \\ wagner.911@osu.edu
}

* Corresponding author. 


\begin{abstract}
In this paper, we chronicle key U.S. legislative initiatives during the post-World War II history of public policy related to the ownership of publicly funded research-based knowledge. Our motivation for recording this history is the observation that many scholars, who are appropriately concerned about taxpayer rights, have argued for the need for public policy to clarify ownership of the publicness or openness of publicly funded research results when in fact such public policies have long been in place. We conclude this historical trace with the proposition that if the past is prologue to the future, one might expect future administrations to continue to acknowledge the importance of public access to findings from publicly funded research, be that research having occurred in federal laboratories, universities, or private-sector organizations.
\end{abstract}

Keywords: Publicly funded R\&D, open access, National Technical Information Service, Bayh-Dole Act, Stevenson-Wydler Act

JEL Codes: H11, H54, O34 


\section{The Publicness of Publicly Funded Research}

We dance round in a ring and suppose, but the secret sits in the middle and knows.

—Robert Frost, The Secret Sits

\section{Introduction: Setting the Stage}

U.S. policy to provide public funding of research and development (R\&D), as well as the infrastructure to support it, has been promulgated with the goal of enhancing the public good. It is widely accepted by economists that measures aimed at increasing basic research will improve social welfare and economic growth. R\&D funding and infrastructure have taken a number of forms over time, and through a variety of processes the dissemination and diffusion of the findings from publicly funded R\&D have similarly been differentiated. ${ }^{1}$

The underlying policy has been to encourage research practitioners to move from conduct to diffusion of knowledge; the public sector has established a number of services and policies to enhance the dissemination of knowledge. As the so-called open access movement has flourished, it is important to revisit government policy toward the dissemination of such research results, and the dissemination of such research findings has a history that is as long as the republic itself. ${ }^{2}$

Our nation's Founding Fathers of the Constitution believed that the government should be an influential force in the promotion of science and technology, but that force should be exerted indirectly. ${ }^{3}$ Article I, Section 8 , of the Constitution states:

\footnotetext{
${ }^{1}$ Despite $19^{\text {th }}$ century interest in public sector investments in R\&D, it was not until 1911 that a line item for R\&D appeared in the U.S. budget.

${ }^{2}$ Throughout this paper we use the term government to refer to national and federal levels. To the best of our knowledge there are not similarly expansive initiatives at the state or regional levels. However, the governmental initiatives discussed herein are applicable to economic units at all levels of aggregations.

${ }^{3}$ The term Founding Fathers refers to "that generation of men who were active in the American Revolution and the formation of the early American Republic and the Constitution." See, https://oll.libertyfund.org/group/the-foundingfathers-of-the-u-s-constitution.
} 
The Congress shall have the power ... To promote the progress of science and useful arts, by securing for limited times to authors and inventors the exclusive right to their respective writings and discoveries.

Nowhere in the Constitution does it direct the mentioned "authors and inventors" to engage in a specific or predetermined area of "science and the useful arts." On the contrary, the Founding Fathers realized that an "exclusive right" would be an incentive to others to pursue their "writings and discoveries." And, nowhere in the Constitution does it direct the government to fund "writings and discoveries."

Perhaps the first post-Constitution example of the philosophical belief of the social benefits of an indirect role of the government in inventive activity was through the passage of the Patent Act of $1790 .{ }^{4}$

However, there are counter examples in America's early history of an indirect role of government in the creation of knowledge. For example, President Jefferson believed that at times the role of the government should be direct. For example, he, as President, sponsored the Lewis and Clark expedition in 1803 with the intent of advancing geographic knowledge and "the promotion of the general welfare depended heavily upon advances in scientific knowledge" (UNESCO, 1968, p. 11). In 1838, President van Buren similarly took the position of the government having a direct role in the support of technological knowledge. Samuel Morse had demonstrated the feasibility of the electric telegraph, and thus the van Buren Congress awarded Morse \$30,000 to build an experimental telegraphic line between Baltimore, Maryland, and Washington, DC (UNESCO, 1968). ${ }^{5}$

\footnotetext{
${ }^{4}$ See, https://fraser.stlouisfed.org/title/patent-act-1790-5734.

${ }^{5}$ Link (2006) argued that the Lewis and Clark expedition represented the first instance of public support of pure or basic research whereas Morse's telegraphic line represented the first instance of publicly supported applied research. The geography knowledge of Lewis and Clark had the characteristics of a public good, and the public sector did not appropriate the knowledge that it funded. The telegraphic line that Morse constructed was however owned by the government, but the spillover knowledge from this new technology was accessible to anyone for a fee.
} 
One might conclude that in the half of a century between the signing of the Constitution in 1787 and Congress's support of the Morse telegraphic line in 1838, the pendulum had made a complete ideological swing from government having an indirect influence on the development of science and technology to it having a direct influence. In fact, to maintain such a direct influence, Congress sought infrastructures to identify scientific areas of national importance. For example, in 1884, Congress established the Allison Commission (Guston, 1994, p. 27): ${ }^{6}$

[T]he Allison Commission ... viewed the scientific bureaux as objects to be manipulated to serve the narrow interest of protecting the power of congressional committees.

Members of Congress, responding to the new demands of scientists ... attempted to invent new mechanisms of control in order to inform themselves about the activities of scientists and to hold them accountable.

Many scholars today trace arguments about the public sector having an indirect influence or a direct influence on the direction of science and technology research to the debate between Senator Kilgore (WV, D) and Vannevar Bush in the early 1940s. ${ }^{7}$ As Brooks (1996, p. 16) pointed out:

Bush selected the university as the centerpiece of postwar science policy specifically because of its independence and autonomy.

whereas Senator Kilgore called for:

\footnotetext{
${ }^{6}$ Guston (1994, p. 52) concluded his treatise on the Allison Committee with a statement that might be prologue to future Congressional action: "The mechanisms of controls ... by the Allison Commission ... stand as early examples of how Congress may continue to exert its constitutional authority to scrutinise an innovative and entrepreneurial scientific community."

${ }^{7}$ However, as Brooks (1996, p. 15) correctly pointed out the lineage to the Kilgore - Bush debate traces to the Polanyi - Bernal debate in Great Britain in the 1930s: "Polanyi stressed the need for autonomy and self-governance of the scientific community if it were to contribute most efficiently to societal goals in the long run ... Bernal, who was strongly influenced by Marxist thought, saw tremendous inefficiencies with autonomous science and believed that its enormous potential benefits for humanity could be realized only through a publicly debated plan involving government and many representative elements of society."
} 
... a much closer linkage to political institutions and less autonomy for the scientific

community in setting the [national] research agenda.

An argument surfaced in the Kilgore - Bush debate that transcended the role of the government having an indirect versus direct influence on the nation's scientific research agenda, one that has echoed through many subsequent policy debates about R\&D funding. Sampat 2020 (p. 43), for example, articulated this argument in the following manner:

Equally contentious, but perhaps less well known, was the question of taxpayer rights in patents arising from government-funded research. Kilgore complained about government funded ideas being given away ... Bush worried that government control of such patents would reduce commercialization incentives and public-private interactions.

The purpose of this paper is to chronicle key U.S. legislative initiatives during the post-World War II history of public policy related to the ownership of publicly funded research-based knowledge. In the United States, there is a rich history of legislation related to intellectual property and relevant intellectual property protection mechanisms; however, herein we focus on those that, from our vantage, support the government's view of publicness. ${ }^{8}$ Our motivation for tracing this history though examples is the observation that many scholars, who are appropriately concerned about taxpayer rights, have argued for the need for public policy to clarify ownership of the publicness or openness of findings from publicly funded research when in fact such public policies have long been in place. ${ }^{9}$

The remainder of this paper is outlined as follows. In Section II, we discuss the government's commitment to the sharing of publicly funded research findings in the post-World War II era thought examples of public access to results from publicly funded research. Although World War I did motivate government R\&D spending, the increases were not sustained; but following

\footnotetext{
${ }^{8}$ Such additional examples are the Federal Courts Improvement Act of 1982 and the Leahy-Smith America Invents Act of 2011. These legislations, and others, are definitely important elements of U.S. technology policy because they help to ensure ownership claims of patented intellectual knowledge, but neither, in our minds, is foundational legislation associated with governmental philosophy of making publicly funded research findings public.

${ }^{9}$ See, as an example, Kadakia et al. (2021).
} 
World War II, the U.S. government increased support to most aspects of research, development, testing, and evaluation. These latter activities took on three broad aspects: government investment in its own laboratories (government-owned, government-operated); government investment in basic research to be conducted outside of government; and government investment in contractors to conduct research for government use and application (government-owned, contractor-operated). Each of these functions developed different approaches to sharing the results of their inquiries.

In the aftermath of World War II, laws established that a record of all government-funded R\&D was to be made public unless it was classified for national security purposes. Government investments in basic research were initially proposed by Bush in Science-the Endless Frontier (1945) to be managed by what eventually became the National Science Foundation (NSF); but, before this infrastructure could be established in 1953, the National Institute of Health (later, Institutes of Health) was established and began to fund on its own basic research in biological sciences and medicine. ${ }^{10}$ Similarly, the Department of Defense began to pursue its own basic research agenda. Other agencies later adopted R\&D functions. Government agencies established their own requirements with regard to open sharing of R\&D results. Similarly, government investment in research contractors allowed contractors to develop procedures for holding and sharing R\&D results.

The agency-based requirements and guidelines on open sharing of the results of publicly funded R\&D differ among themselves. For example, the National Science Foundation and the National Institutes of Health require any publication resulting from grant-based research to be publicly available within 12 months of publication. This 12-month period allows researchers to publish in subscription-based journals that allow exclusive access to subscription holders for a brief period of time before the publication is publicly available. There are no government-imposed restrictions on providing a version of research results in pre-print servers. In fact, the most well-

\footnotetext{
${ }^{10}$ See Link (forthcoming) and the references therein for a more detailed discussion of the Kilgore - Bush debate and Bush's views as reflected in Science - the Endless Frontier.
} 
known pre-print server, arXiv, was created at Los Alamos National Laboratory and partly funded by NSF to serve the physics community with rapid access to research.

In the following Section II, we detail three key governmental efforts to curate and disseminate the results of R\&D funding. We focus on these three examples because of the conceptual foundation they established for an indirect role of government. The earliest formal vessel to carry forth government research results was established in 1950 with the formation of the National Technical Information Service (NTIS). We also discuss the Bayh-Dole Act of 1980 and the Stevenson-Wydler Act of 1980. Finally, in Section III we conclude the paper with a summary of the historical trace of the activities of government's commitment to sharing research findings.

\section{An Historical Trace}

\section{A. National Technical Information Service}

On June 12, 1945, President Truman signed Executive Order 9568 which created the Publication Board, and which provided for the release of scientific information "to the end that such information may be of maximum benefit to the public." 11 The Publication Board was: ${ }^{12}$

... the first effort by the government to collect, organize, and distribute a wide range of federally sponsored research in diverse disciplines to interested groups in the private sector. In effect, this was the beginning of the use of the technical report as an instrument for the mass release of scientific and technological data.

Later in 1945, the Publication Board was merged into a new unit, the Office of Technical Services, (OTS), within the Department of Commerce (Stewart, 1993). In 1950, authority for what was to become the National Technical Information Service (NTIS) was granted by Congress through an act to provide for the dissemination of technological, scientific, and

\footnotetext{
${ }^{11}$ See, https://www.loc.gov/item/fr010116/. This executive order was amended several times. See, https://www.archives.gov/federal-register/executive-orders/1945-truman.html.

${ }^{12} \mathrm{See}, \underline{\mathrm{https}} / / / \mathrm{www} \cdot$ loc.gov/rr/scitech/trs/trspb.html.
} 
engineering information to American business and industry, and for other purposes: Public Law 81-776. The act states:

The Secretary of Commerce ... is hereby directed to establish and maintain within the Department of Commerce a clearinghouse for the collection and dissemination of scientific, technical, and engineering information, and to this end to take such steps as he may deem necessary and desirable ... To make such information available to industry and business, to State and local governments, to other agencies of the Federal Government, and to the general public ...

In 1964, the Clearing House for Federal Scientific and Technical Information (CFSTI) was created in the National Bureau of Standards (within the Department of Commerce, later renamed the National Institute of Standards and Technology) to replace OTS. In 1970, CSFTI was renamed NTIS under Department of Commerce Order 30-7A. ${ }^{13}$

Today, the strategic focus of NTIS is: ${ }^{14}$

... to expand access to data resources, with an emphasis on data concerning the nation's economy, population, and environment. NTIS serves government agencies by providing solution services to readily available data products. Partnering with companies (Joint Venture Partners) that are industry leaders in data discovery, usability, accessibility, interoperability, analytics, security, and privacy, ensures NTIS achieving the core data mission to become a center of excellence in data science.

More specifically, according to 15 U.S. Code $\S 3704 b$ :

The Secretary of Commerce, acting through the Service, shall-(1) establish and maintain a permanent repository of nonclassified scientific, technical, and engineering information ...

\footnotetext{
${ }^{13}$ See, https://www.osec.doc.gov/opog/dmp/doos/doo30_7a.html.

${ }^{14} \mathrm{See}$, https://www.ntis.gov/federal-data-products.xhtml.
} 
Also, as stated in the American Technology Preeminence Act of 1991, Public Law 102-245:

The head of each Federal executive department or agency shall transfer in a timely manner to the National Technical Information Service unclassified scientific, technical, and engineering information which results from federally funded research and development activities for dissemination to the private sector, academia, State and local governments, and Federal agencies. Only information which would otherwise be available for public dissemination shall be transferred under this subsection.

The National Technical Reports Library (NTRL) within NTIS provides (as of 2016) the public an open-access website to more than 3 million records and abstracts and over 800,000 digitized reports. ${ }^{15}$

\section{B. The Bayh-Dole Act of $1980^{16,17}$}

The legislative process which led to the passage of the Bayh-Dole Act began on March 26, 1980 as H.R. 6933. ${ }^{18}$ The Act was introduced in the aftermath of a productivity slowdowns in various sectors of the U.S. economy. ${ }^{19}$ Also influencing the legislators were the writings of economists, such as Nelson (1962) and Arrow (1962), who pointed out reluctance of private companies to commercialize publicly available knowledge. Private companies may be unwilling to commercialize widely available basic knowledge since it would be difficult to gain a competitive edge in the marketplace.

\footnotetext{
${ }^{15}$ See, https://ntrl.ntis.gov/NTRL/.

${ }^{16}$ The full title of this Act is the Patent and Trademark Act Amendments of 1980: Public Law 96-517. It is also referred to as University and Small Business Patent Procedure Act of 1980.

${ }^{17}$ This section draws directly from Gores and Link (2021). For a more detailed discussion of the underlying legislation see Link and Cunningham (2021).

${ }^{18}$ A legislative history of H.R. 6933 is available at 20 House Report No. 96-1307, 96th Cong., 2d Sess. (1980).

${ }^{19}$ The Economist (2002) referred to this period of time before the passage of the act as the period of "technological malaise that befell America in the late 1970s." See Link and Cunningham (2021) for more information about the productivity slowdown.
} 
President Carter's policy prescriptions for reversing this productivity decline were set forth, at least in part, in what has become known as his Domestic Policy Review (Joint Hearings, 1979). ${ }^{20}$ Therein the President's remarks were:

I will also support the retention of patent ownership by small business and universities [emphasis added], the prime thrust of legislation now in Congress, in recognition of their special place in our society.

The Bayh-Dole Act states:

It is the policy and objective of the Congress to use the patent system to promote the utilization of inventions arising from federally supported research or development; to encourage maximum participation of small business firms in federally supported research and development efforts; to promote collaboration between commercial concerns and nonprofit organizations, including universities; to ensure that inventions made by nonprofit organizations and small business firms are used in a manner to promote free competition and enterprise; to promote the commercialization and public availability of inventions made in the United States by United States industry and labor; to ensure that the Government obtains sufficient rights in federally supported inventions to meet the needs of the Government and protect the public against nonuse or unreasonable use of inventions; and to minimize the costs of administering policies in this area.

The Bayh-Dole Act was one of several reasoned policy responses to the productivity slowdown that plagued the private sector of the United States. ${ }^{21}$ The argument behind this policy emerged from economics research which suggested that limited ownership or temporary protection was needed to incentivize risk-takers to commercialize knowledge that would otherwise reside in the public sector. $^{22}$

\footnotetext{
${ }^{20}$ See: President Carter's Industrial Innovation Initiatives Message to the Congress on Administration Actions and Proposals (Joint Hearings, 1979).

${ }^{21}$ These policy responses included the Stevenson-Wydler Act of 1980 (discussed below), the R\&E tax credit of 1981, the Small Business Innovation Development Act of 1982, and the National Cooperative Research Act of 1984.

${ }^{22}$ See, Arrow (1962)
} 
University-based research is basic in its nature in comparison to the applied research and/or development that takes place in the private sector. Thus, university-based research has a public good characteristic, and therefore that knowledge enters the public domain through publications and conference presentations because it is not appropriable. ${ }^{23}$ However, it is not uncommon for follow-on research to occur at a university that is of an applied nature and thus is patentable and therefore appropriable by the university.

In defense of criticism of Bush's view of the role of government being indirect, one should recognize that the government legislated march-in rights as stated in the act: ${ }^{24}$

\begin{abstract}
With respect to any subject invention ... the Federal agency under whose funding agreement the subject invention was made shall have the right ... to grant such a license itself, if the Federal agency determines that [is warranted for the commonweal].
\end{abstract}

Even with controversary, other countries have adopted the Bayh-Dole Act as, like in the United States, a model for legislation with the intent to inject new technology (i.e., publicly funded technical knowledge) into the economy to stimulate economic growth. ${ }^{25,26}$

\title{
C. Stevenson-Wydler Act of $1980^{27}$
}

In many respects, the federal laboratory focus of the Stevenson-Wydler Act is similar to the small business and university focus of the Bayh-Dole Act.

\footnotetext{
${ }^{23}$ One might trace arguments to support the public sector's support of basic knowledge to Flexner (1939) as well as to Arrow (1962).

${ }^{24}$ However, in response to high and rising drug prices by pharmaceutical companies that licensed a university patent, some have been critical of the Bayh-Dole Act because march-in rights have not yet been exercised by a funding agency. See, https://www.jdsupra.com/legalnews/changes-to-march-in-rights-under-bayh-1121759/\#ft5. See also Link et al. (2018), Marr and Phan (2020), and Sampat (2020).

25 "Imitation is the sincerest form of flattery that mediocrity can pay to greatness." - Oscar Wilde.

${ }^{26}$ See, Gores and Link (2021) for a discussion of the globalization of the Bayh-Dole Act and a description of the Bayh-Dole like initiatives in other countries.

${ }^{27}$ The full title of this Act is the Stevenson-Wydler Technology Innovation Act of 1980: Public Law 96-480.
} 
According to the Stevenson-Wydler Act:

The Congress finds and declares that: Technology and industrial innovation are central to the economic, environmental, and social well-being of citizens of the United States. Technology and industrial innovation offer an improved standard of living, increased public and private sector productivity, creation of new industries and employment opportunities, improved public services and enhanced competitiveness of United States products in world markets. Many new discoveries and advances in science occur in ... Federal laboratories, while the application of this new knowledge to commercial and useful public purposes depends largely upon actions by business and labor ... The Federal laboratories and other performers of federally funded research and development frequently provide scientific and technological developments of potential use to State and local governments and private industry. These developments should be made accessible to those governments and industry. There is a need to provide means of access and to give adequate personnel and funding support to these means ... It is the purpose of this Act to improve the economic, environmental, and social well-being of the United States by ... promoting technology development through the establishment of centers for industrial technology [within Federal laboratories and] stimulating improved utilization of federally funded technology developments by State and local governments and the private sector ... It is the continuing responsibility of the Federal Government to ensure the full use of the results of the Nation's Federal investment in research and development. To this end the Federal Government shall strive where appropriate to transfer Federally owned or originated technology to State and local governments and to the private sector.

Each federal laboratory was mandated to establish a technology transfer office to be referred to as an Office of Research and Technology Applications (ORTA):

Each Federal laboratory shall establish an Office of Research and Technology Applications. Laboratories having existing organizational structures which perform the functions of this section may elect to combine the Office of Research and Technology Applications within the existing organization. 
The function of each ORTA was defined to:

... prepare an application assessment of each research and development project in which that laboratory is engaged which has potential for successful application in State or local government or in private industry ... provide and disseminate information on federally owned or originated products, processes, and services having potential application to State and local governments and to private industry ... cooperate with and assist the Center for the Utilization of Federal Technology and other organizations which link the research and development resources of that laboratory and the Federal Government as a whole to potential users in State and local government and private industry ... and provide technical assistance in response to requests from State and local government officials.

The annual editions of the Code of Federal Regulations (CFR) contains the codification of the general and permanent rules published in the Federal Register by the departments and federal agencies. ${ }^{28}$ Using the Department of Energy as an example, ${ }^{29}$ it has an Office of Scientific and Technical Information (OSTI) which, in concept, is an expansion of the initial responsibility to establish an ORTA. OSTI was formalized through the Energy Policy Act of 2005: Public Law 109-58:

The Secretary, through the Office of Scientific and Technical Information, shall maintain within the Department publicly available collections of scientific and technical information resulting from research, development, demonstration, and commercial applications activities supported by the Department.

Currently, as stated in the CFR in 935.010 Scientific and Technical Reports:

\footnotetext{
${ }^{28} \mathrm{See}, \mathrm{https}: / /$ www.govinfo.gov/help/cfr.

${ }^{29}$ There are many other examples including the National Library of Medicine, which has been on the National Institutes Campus since the early 1960s, the creation of a medical journal database within MEDLINE in the 1970s, and a search engine for the status of clinical trials (www.ClinicalTrials.gov) at the turn of this century.
} 
(c) All research and development contracts which require reporting of research and development results conveyed in scientific and technical information (STI) shall include an instruction requiring the contractor to submit all STI, including reports and notices relating thereto, electronically to the U.S. Department of Energy (DOE), Office of Scientific and Technical Information (OSTI), using the DOE Energy Link System.

\section{The Past is Prologue}

In this final section, we overview the themes from the three examples we have previously discussed of the U.S. government's commitment to sharing publicly funded research findings. Motivating this paper, which we mentioned in Section I, is the reoccurring observation that policy makers and policy scholars are just now [emphasis added] discovering the social need for publicly funded research results to be a part of the open access public domain. Our historical trace has dated the fact that this awareness traces to political activity beginning in the early 1940s. One might also identify the Kilgore - Bush debate as the salvo for subsequent legislation.

Perhaps what is more important than the dating of the origin of an open access argument is the fact that political leaders have continued for over one-half of a century to make improvements in infrastructures designed for that purpose. For example, in February 2013, the Director of the Office of Science and Technology Policy (OSTP) released a memorandum aimed at increasing access to the results of federally funded scientific research. ${ }^{30}$ The directive in this memorandum is based on the Obama Administration's commitment to: ${ }^{31}$

... ensuring that, to the greatest extent and with the fewest constraints possible and consistent with law ... the direct results of federally funded scientific research are made available to and useful for the public, industry, and the scientific community ... Scientific research supported by the Federal Government catalyzes innovative breakthroughs that drive our economy. The results of that research become the grist for new insights and are

\footnotetext{
${ }^{30}$ This memorandum followed America COMPETES Reauthorization Act of 2010 and President Barack Obama's November 2011 Presidential Memorandum - Managing Government Records. Therein, he made public: “... an executive branch wide effort to reform records management policies and practices. Improving records management will improve performance and promote openness and accountability by better documenting agency actions and decisions."

${ }^{31}$ See, http://obamawhitehouse.archives.gov/sites/default/files/microsites/ostp/ostp_public access memo_2013.pdf.
} 
assets for progress in areas such as health, energy, the environment, agriculture, and national security.

This memorandum initiated an interagency working group through the National Science and Technology Council (NSTC) of the U.S. government dedicated to implementing the President's memorandum widely across government agencies. The interagency working group issued guidelines to enhance openness and expand the definition to include citizen science and crowdsourcing projects, datasets, code, applications, and technologies generated by such projects. $^{32}$

If the past is prologue to the future, one might expect future administrations to continue to acknowledge the importance of public access to results from publicly funded research, be that research having occurred in federal laboratories, universities, or private-sector organizations. Public access to the findings from publicly funded research does have economic benefits, but it also entails economic costs. This is evident, for example, through China's intellectual property violations although many of those violations are with respect to privately funded R\&D. ${ }^{33}$ Public interest in broad access to government-funded $\mathrm{R} \& \mathrm{D}$ will spur additional actions on the part of all practitioners to provide digital access to their research findings so that interested parties, and especially to those in the United States, can engage in furthering research and innovation.

Additional research is clearly warranted on topics beyond the focus of this paper. As we stated in the Introduction, this paper addresses examples in the history of public policy related to the ownership or openness of government or publicly funded research-based knowledge; that is, the results from publicly funded research. The broader topic of open science is beyond the scope of this paper, but an historical chronicle of legislation and agency practices to promote open science in one fashion or another is clearly needed not only for the benefit of institutional history but also to provide context for contemporary policies such as the Foundations for Evidence-Based

\footnotetext{
${ }^{32}$ Guidelines established across agencies for open publication and broad data access can be found at https://cendi.gov, which serves as a clearinghouse for information on access to the results of U.S. government funded R\&D.

${ }^{33}$ See Hickey et al. (2000).
} 
Policymaking Act, Public Law 115-435, and the related OPEN Government Data Act, signed into law in 2019. 


\section{References}

Arrow, Kenneth J. (1962). "Economic Welfare and the Allocation of Resources for Invention," in The Rate and Direction of Inventive Activity: Economic and Social Factors (pp. 609-626), Princeton: Princeton University Press.

Brooks, Harvey (1996). "The Evolution of U.S. Science Policy," in Technology, R\&D, and the Economy (edited by B.L.R. Smith and C.E. Barfield, pp. 15-48), Washington, DC: The Brookings Institution and American Enterprise Institute.

Flexner, Abraham (1939). “The Usefulness of Useless Knowledge,” Harpers, 179: 544-552.

Gores, Thorsten and Albert N. Link (2021). "The Globalization of the Bayh-Dole Act," Annals of Science and Technology Policy, 5: 1-90.

Guston, David H. (1994). "Congressmen and Scientists in the Making of Science Policy: The Allison Commission, 1884-1886," Minerva, 32: 25-52.

Hickey, Kevin J., Nina M. Hart, Brandon J. Murrill, and Kevin T. Richards (2020). Intellectual Property Violations and China: Legal Remedies, Congressional Research Service Report R46532, Washington, DC: U.S. Congress.

Joint Hearings (1979). "Joint Hearings before the U.S. Senate Committee on Commerce, Science, and Transportation and the Select Committee on Small Business; and to the U.S. House of Representatives Committee on Science and Technology and the Committee on Small Business," Washington, DC: Government Printing Office.

Kadakia, Kushal T., Adam L. Beckman, Joseph S. Ross, and Harlan M. Krumholz (2001). "Leveraging Open Science to Accelerate Research," New England Journal of Medicine, DOI: $10.1056 / \mathrm{NEJMp} 2034518$.

Link, Albert N. (2006). Public/Private Partnerships: Innovation Strategies and Policy Alternatives, New York: Springer.

Link, Albert N. (forthcoming). "Vannevar Bush: A Public Sector Entrepreneur," Foundations and Trends in Entrepreneurship.

Link, Albert N. and James A. Cunningham (2021). Advanced Introduction to Technology Policy, Northampton, MA: Edward Elgar.

Link, Albert N., Robert S. Danziger, and John T. Scott (2018). "Is the Bayh-Dole Act Stifling Biomedical Innovation?" ISSUES in Science and Technology, Winter: 33-35. 
Marr, Kieren and Phillip Phan (2020). "The Valorization of Non-Profit Intellectual Property in Academic Medical Centers," Journal of Technology Transfer, 45: 1823-1841.

Nelson, Richard R. (1962). "Introduction to The Rate and Direction of Inventive Activity: Economic and Social Factors," in The Rate and Direction of Inventive Activity: Economic and Social Factors (pp. 1-16), Princeton: Princeton University Press.

Sampat, Bhaven N. (2020). "Whose Drugs Are These? ISSUES in Science and Technology, Summer: $42-48$.

Stewart, Robert K. (1993). "The Office of Technical Services: A New Deal Idea in the Cold War," Knowledge, 15: 44-77.

The Economist (2002). “Innovation's Golden Goose,” https://www.economist.com/technologyquarterly/2002/12/14/innovations-golden-goose.

UNESCO (1968). National Science Policies of the U.S.A.: Origins, Development and Present Status. Paris: Unesco. 